\title{
Public Service Leadership Competency Framework [PSLCF]: Is It a Holy Grail of Service Delivery?
}

\author{
Ramadhani Marijani \\ Tanzania Public Service College [TPSC], Tabora, Tanzania \\ Email: ramadhani.marijani@tpsc.go.tz
}

How to cite this paper: Marijani, R. (2017) Public Service Leadership Competency Framework [PSLCF]: Is It a Holy Grail of Service Delivery? Open Journal of Social Sciences, 5, 169-184. https://doi.org/10.4236/jss.2017.510015

Received: September 9, 2017

Accepted: October 16, 2017

Published: October 20, 2017

Copyright $\odot 2017$ by author and Scientific Research Publishing Inc. This work is licensed under the Creative Commons Attribution International License (CC BY 4.0).

http://creativecommons.org/licenses/by/4.0/

\begin{abstract}
This paper evaluates Tanzania Public Service Leadership Competency Framework [TPSLCF] so as to establish the extent to which it addresses the core knowledge needs of the government. Based on public administration viewpoint, semantic and linguistic analyses are used to compare the knowledge needs of the government as proposed by the President's inaugural speech, the national research priorities and the TPSLCF. The findings indicate that to a large extent, the TPSLCF addresses the core knowledge needs of the government and therefore has the potential to improve public service delivery. However, the findings further signify that currently the TPSLCF does not stand as a holy grail of service delivery as there are some critical facets in it which need improvement. It is recommended in this paper that there is a need to review and customize TPSLCF as the way to align it with the current and future needs of the leaders and the governments. The article concludes with implications for future research and practices.
\end{abstract}

\section{Keywords}

Leadership, Competency, Public Service, Knowledge, Service Delivery

\section{Introduction}

The recent past has witnessed a renewed and growing interest in improving the quality of governance and government elsewhere in the world [1]. The reasons for this development are diverse. First, there are significant economic, social and institutional changes that bedeviled the past two decades. Second, there have been reform initiatives in many countries which have also contributed enormously to the governance interest. Third, the United Nations and her agencies like 
the World Bank and other regional associations of governments have also been the key contributors to this process [1].

In African countries, the social-economic crises over the last two decades have inspired governments to search for new solutions. As a result, governments and citizens from all over Africa are now engaged in various forms of transforming their public services [2]. These transformations promise to have the far-reaching implications for a wide range of global, national, and micro-issues including service delivery, human rights and individual human quality of life, competencies and capacities, management and governance systems, global markets, regional peace and national economics.

By and large, the said transformation has been essentially driven by the quest for improved efficiency in service delivery and reduced cost [3]. In this endeavor, rather than passively accepting solutions designed by others, as happened in the past with Structural Adjustments Programs (SAPs) and Poverty Reduction Strategic Papers (PRSPs), the new generation of African leaders is attempting to come up with African solutions to African problems [3].

Thus, the constitutive Act of the African Union (AU) has orchestrated a fundamental shift in our understanding of the relationship between the state and the citizens. This understanding challenges all of us to innovate how we shape and deliver public services. The complexities of the quality of life of African people necessitate the constant need to seek out new ways of delivering services. Innovation is thus not only necessary, but also unavoidable and is a key requirement for effective, efficient and responsive public sector delivery and it is basically imperative to the $\mathrm{AU}[2]$.

It is against the above backdrop, that since the late 1990s the momentum to build and sustain collective efforts and support national public administration effectiveness efforts grew in part, as response to broader socio-economic and political changes within the African geo-political architecture (ibid).

Using Tanzania as the case study this paper reflects on the competency knowledge areas proposed by the Tanzania Public Service Leadership Competency Framework [TPSLCF]. The paper attempts to establish whether TPSLCF addresses the core knowledge needs of the government by solving the daily operational problems and therefore improving service delivery or not. To respond to this empirical opaque, an analysis is done on a) The speech by the President of United Republic of Tanzania His Excellency Dr. John Pombe Joseph Magufuli, officially inaugurating the $11^{\text {th }}$ Parliament on $20^{\text {th }}$ November, 2015 and b) The Research Priorities for Tanzania 2015-2020 [4].

This paper is structured into six sections. The first section (which comes after the introduction) is about the conceptual framework which presents the meaning of key concepts used to avoid nuance and direct channel of discussions. The second section is dedicated to the related literature review. The third section highlights the core knowledge needs of the government of Tanzania. The fourth section narrows the scope to the assessment of TPSLCF and core knowledge needs of the government. The fifth section dwells on the findings and discus- 
sions and the sixth section draws some concluding remarks.

\section{Definitions of Important Concepts}

Before embarking on the question as to whether the PSLCF really addresses the core knowledge needs of the government of Tanzania or not, it is worth to re-visit the concepts of knowledge, competency, public sector and leadership.

\subsection{Competency}

The term competency has been used to mean very different things to the extent of creating confusion [5]. Four schools are identified in the literature in relation to the use of the term: One school views the competency as representing specific expertise or accomplishment; another school conceive it as the capacity of an organization; it is also taken to mean specific behaviors contributing to excellence; and finally, there are those who views competency as a minimal level of job proficiency [5] [6].

According to [7], competencies are those underlying characteristics which are causally related to effective or superior job performance. Refer [8] expands the term competency beyond traditional knowledge, skills, and abilities [KSAs] to enmesh job-related motives, traits and self-concepts. Furthermore, [9] remind us that competencies are distinguishable from KSAs as they focus on future development and potential for performance.

\subsection{Public Sector}

Public Sector is a set of public institutions that coordinate the interests of different groups that ask in various ways for public activities of different kinds [10]. To Political scientists, public sector includes both what kind of activities public institutions carry out and how decision are made and implemented by these institutions [10].

\subsection{Leadership}

In this paper leadership is defined as "influencing others to accomplish organizational goals" [11].

\subsection{Knowledge}

This is an "activity which can well be described as a process of knowing" [12] [13]. The focus of this paper is to link TPSLCF and the needed knowledge, skills, abilities and behavior for improved service delivery.

\section{Literature Review}

\subsection{The Evolution of Competencies: Re-Visited}

Competencies Frameworks in the United States are theoretically based on behavioral psychology [14]. Of late competency programmes draw much from the works of [15]-[20] and [21]. It is instructive for us to trace the contributions of 
these scholars as they widen up our understanding of the evolution of competency-oriented thought.

\subsection{A Cradle of Competency Modelling: The John Flanagan Contribution}

A seminal article by John Flanagan published in the Psychology Bulletin in 1954 introduced the Critical Incident Technique [CIT] as the cradle to the key methodology used in competency studies [15] [14]. The article highlights the odyssey of the Critical Incident Technique, as the outgrowth of studies in the Aviation Psychology Programme of the United States Army Air Forces in World War II between 1941-1946.

Later on some psychologists who were part of the United State Army Air Forces [USAAF] and Aviation Psychology Programme established the American Institute of Research to extend the research works and in 1947 the Critical Incident Technique [CIT] was formally developed and given its present name [15]. Equally, the department of psychology at the University of Pittsburgh continued to research on the concept by developing a research agenda in this line of thinking where by number of students researched in this area as partial fulfillment for the awards of higher degrees under the supervision of Flanagan in 1949.

Generally, the aforementioned studies focused on issues related to aircraft pilot performance such as "failure in learning to fly", "reasons for failure in bombing missions", "combat leadership problems", "critical requirements for dentists", "critical requirements for industrial foremen" and "instructors for general psychology course" [15].

From above studies, Flanagan concluded that "the principal objectives of job analysis procedures should be the determination of critical requirements". The critical requirements entails any observable human activity that is sufficiently complete in itself to permit inferences and predictions to be made about the person performing the job, between success and failure in carrying out an important part of the job assigned in a significant number of incidences [15].

Eventually, the article recommend five main steps procedures to be employed in undertaking the critical incident techniques, which includes; 1) Determination of the general aim of the activity 2) Development of the plans and specifications for collecting factual incidents regarding the activity 3) Data collection 4) Data analysis; and 5) Interpretation and reporting of the statement of the requirements of activity. Much of this work did not directly refer to "competencies" it provided the foundation of the concept by providing the criteria of examining what people do [14]. The foregoing discussions means that competencies imply the capacity to successful accomplish a certain tasks, and therefore differentiate the capable from the incapable.

\subsection{The Building Blocks of Competency Modelling: The Robert White and David McClelland Contributions}

In his paper entitled "Motivation Reconsidered: the Concept of Competence" 
Robert White identified a human trait that he called "competence" [16]. Building and extending on White's work David McClelland who was the Professor of Psychology at Harvard University and founder of McBer and company published a seminal paper in 1973 entitled "Testing for Competency rather than Intelligence". The paper stirred up the blood of industrial psychologists [17] [21]. Refer [17] for example, argued that it was possible to identify personality traits or competencies that could predict even better than traditional academic aptitude and knowledge content tests. He concluded that "best predictors of outstanding on-the-job performance were underling, enduring personal characteristics called competencies" [17]. Most importantly, once these behaviors separating exemplary performers from the average one are known, they could be taught to others [22]. In this line of thinking, McClelland reminds us that determination of individual performance should go beyond academic performance as there are other personal factors that should also be relied up on, those characteristics were christened "competencies" and can easily be taught to others.

\subsection{Competency and Organizational Capability: Beyond Educational Utility}

While McClelland's work was largely applied in the educational sector, it was the business and industry world that showed greater interest and in 1970s McBer and Company of which McClelland was one of the core founders teamed up with American Management Association [AMA] and for the first time undertook the large scale competency programme of its time [14]. The key research question was "what competencies are exhibited by the exemplary performers that non performers do not exhibit? The study findings identified the following competencies essential to the exemplary performers;

1) Specialized knowledge

2) Intellectual maturity

3) Entrepreneurial maturity

4) Interpersonal maturity, and

5) On-the-job maturity

Extending from these findings Patricia McLagan invoked competency models in planning, organizing, integrating and improving all human resource functions [18]. Richard Boyatzis further took over from Patricia McLagan and published a book in 1982 entitled "The Competent Manager: A Model for Effective Performance", where he contextualizes training and development interventions to suit the corporate culture and specific group [6]. It was with Boyatzis that job competency come to limelight as "an underlying characteristics of a person that leads to or causes superior performance" [14].

\subsection{The Public Sector Innovation: A Need for Leadership Competency Frameworks (PSLCFs)}

Plethora of public sector reforms initiatives implemented by several govern- 
ments over the recent past originated from the private sector [5]. To mention but not the only one is the New Public Management (NPM) which stresses on the adoption of private sector business principles. Moreover, the NPM managerial views staunchly heralded the emphasis on innovation, results-based accountability and leadership, provided the impetus for the governments to use of leadership competencies to improve service delivery [5]. The momentum ushered in the competency-based management movement in the late 1960s as the results of changing economic and political context [22].

Table 1 below illustrates the public sector leadership competency frameworks that have been used by seven different governments:

Without delving into specific country's model, the following general observations can be highlighted;

First and foremost, much as there is obvious overlap between the models, with numerous related competencies such as people mobilization, engagement, and strategic management there is also glaring differences in the content and

Table 1. Public sector leadership competency models.

\begin{tabular}{|c|c|c|c|c|c|c|}
\hline AUSTRALIA & UNITED STATES & CANADA & $\begin{array}{c}\text { UNITED } \\
\text { KINGDOM }\end{array}$ & SOUTH AFRICA & NEW ZELAND & NETHERLANDS \\
\hline $\begin{array}{c}\text { Senior Executive } \\
\text { Leadership } \\
\text { Capability } \\
\text { Framework[2001] } \\
\text { and Integrated } \\
\text { Leadership System } \\
{[2004]}\end{array}$ & $\begin{array}{c}\text { Executive core } \\
\text { Qualifications } \\
{[2006]}\end{array}$ & $\begin{array}{l}\text { Key Leadership } \\
\text { Competencies } \\
\text { Model [2004] }\end{array}$ & $\begin{array}{c}\text { Civil Service } \\
\text { Competency } \\
\text { Framework [2012] }\end{array}$ & $\begin{array}{l}\text { SMS Competency } \\
\text { Framework [2011] }\end{array}$ & $\begin{array}{c}\text { Chief Executive } \\
\text { Competency Profile } \\
\text { [2009] }\end{array}$ & $\begin{array}{c}\text { Competencies for } \\
\text { Senior Managers } \\
{[2000]}\end{array}$ \\
\hline Strategic Thinking & Leading Change & $\begin{array}{l}\text { Strategic } \\
\text { Thinking }\end{array}$ & $\begin{array}{l}\text { Setting Directions } \\
\text { [Strategic Cluster] }\end{array}$ & Core Competencies & $\begin{array}{c}\text { Strategic } \\
\text { Leadership }\end{array}$ & $\begin{array}{l}\text { Coherent } \\
\text { Governance }\end{array}$ \\
\hline $\begin{array}{l}\text { Cultivate } \\
\text { Productive work } \\
\text { relationships }\end{array}$ & Building Coalitions & Engagement & $\begin{array}{l}\text { Engaging people } \\
\text { [People cluster] }\end{array}$ & $\begin{array}{c}\text { Process } \\
\text { Competencies }\end{array}$ & $\begin{array}{c}\text { Personal and } \\
\text { Interpersonal Skills }\end{array}$ & $\begin{array}{c}\text { Interpersonal } \\
\text { Behavior }\end{array}$ \\
\hline Achieves Results & Results Driven & $\begin{array}{l}\text { Management } \\
\text { Excellence }\end{array}$ & $\begin{array}{l}\text { Delivering Results } \\
\text { [Performance } \\
\text { Cluster] }\end{array}$ & & Operating Skills & $\begin{array}{l}\text { Operational } \\
\text { Effectiveness }\end{array}$ \\
\hline $\begin{array}{l}\text { Exemplifies } \\
\text { Personal Drive } \\
\text { and Integrity }\end{array}$ & Leading People & Values and Ethics & Civil Service Values & & $\begin{array}{l}\text { Acting with } \\
\text { Honour and } \\
\text { Integrity }\end{array}$ & $\begin{array}{l}\text { Governance } \\
\text { Sensitivity }\end{array}$ \\
\hline $\begin{array}{l}\text { Communicates } \\
\text { with Influence }\end{array}$ & Business Acumen & & & & $\begin{array}{l}\text { Organizational } \\
\text { positioning Skills }\end{array}$ & Problem Solving \\
\hline & & & & & $\begin{array}{c}\text { Courage } \\
\text { Energy and Drive }\end{array}$ & $\begin{array}{c}\text { Impact } \\
\text { Resilience }\end{array}$ \\
\hline $\begin{array}{l}5 \text { Core capability } \\
\text { clusters with } 22 \\
\text { overall } \\
\text { competencies }\end{array}$ & $\begin{array}{l}5 \text { ECQs with } 28 \\
\text { overall } \\
\text { competencies, } 6 \text { of } \\
\text { which are deemed } \\
\text { to be fundamental } \\
\text { competencies }\end{array}$ & 4 Competencies & $\begin{array}{l}3 \text { Clusters } \\
\text { with } 10 \text { overall } \\
\text { competencies, } \\
\text { with values } \\
\text { underpinning all } \\
\text { competencies }\end{array}$ & $\begin{array}{c}5 \text { Core } \\
\text { competencies with } \\
5 \text { distinct process } \\
\text { competencies all } \\
\text { of which are } \\
\text { applied against } \\
\text { each of the core } \\
\text { competencies }\end{array}$ & 7 Competencies & $\begin{array}{l}7 \text { Clusters with } 4 \\
\text { competencies for } \\
\text { each cluster [ } 28 \\
\text { overall } \\
\text { competencies] }\end{array}$ \\
\hline
\end{tabular}

Source: Adapted from [5]. 
complexity of models. Second, most of the models are very generic, and third, of the seven models only two (the UK and Canadian) heralded the public service values and ethics. This is alarming as the values and ethics are very central to the success of leadership competency models [5].

Despite the above observation, the competency models are very popular to date. As [23] remind us, organizations use competencies for several reasons: First, to increase the performance of employees through appraisal, training, and other personnel practices, second, they are used in articulating the corporate values and objectives.

\section{The Core Knowledge Needs of the Tanzanian Government}

Reviewing the core knowledge needs of the government is not an easy task as the government comprises of the institutions at the national, provincial and local levels with different needs [15]. It becomes herculean task when is done by the academic or researcher. As [24] observed that there is often an uneasy relationship between researchers and policy practitioners with different perspectives on what the problem [needs] is, and unrealistic expectation of each other.

It is therefore instructive in this context to borrow a suggestion from [25] who proposed that an understanding of government priorities must include the best possible assessment of future government priorities. That is why, Wessel's in concurring with Baehler's suggestion offers two sensible pointers to follow when looking for the core knowledge needs of the government; namely the Presidential address to the Parliament and the National Research Foundation research focus areas [13].

To be safe in using the two pointers the categories for categorizing research issues in public administration are developed, as the two indicators may also contain possible research priority areas beyond public administration discipline focus [26] [13] [27]. The analysis reveals the following (Table 2) possible knowledge needs of the government.

Analysis of the President Speech reveals number of issues which are very vital for the performance of the government, as revealed by the above eleven clusters (Table 2). In the clusters, there is one important knowledge need area that is missing, that is, the "Information, Communication and Technology" which is very fundamental for the government of the day.

The Tanzania National Research Agenda [NRA] for 2015-2020 was prepared by the Tanzania Commission for Science and Technology [COSTECH] with the aim of consolidating and coordinating research activities to realize the Tanzania Development Vision [TDV] 2025 [28]. The NRA indicates priority research areas in Tanzania where researchers across different disciplines should focus in order to stimulate socio-economic development in the country. Below are NRA priorities:

- Human Capital Development and Quality Livelihood [Healthy, food quality, safety and nutrition, water and sanitation, land management and human settlement]. 
Table 2. Knowledge needs of the Tanzanian Government according to the speech of President Magufuli.

\begin{tabular}{|c|c|}
\hline Unit Standard Category & Knowledge Needs of the Government \\
\hline \multirow{9}{*}{ Managing Public Service delivery [PSD] } & 1) Supervising expenditure of public property and national resources \\
\hline & 2) Bring about fair distributions of resources \\
\hline & 3) A review of performance practices of state-owned enterprises [Tanzania Harbors Au- \\
\hline & thority, Tanzania Revenue Authority, Tanzania Electricity Company] \\
\hline & $\begin{array}{l}\text { 4) Improvement of social service [running water, sanitation, electricity, health services } \\
\text { and education] }\end{array}$ \\
\hline & $\begin{array}{l}\text { 5) Strengthening and improvement of economic infrastructure [ roads, new railway line, } \\
\text { telecommunication] }\end{array}$ \\
\hline & 6) Regional Administration and Local Government Authorities accountability [failure to \\
\hline & collect tax, abuse of office, misappropriation of funds, poor implementation of projects] \\
\hline & 7) Corruption in service delivery. \\
\hline \multirow{5}{*}{ Development Management [DEV] } & $\begin{array}{l}\text { 1) Sector development strategies and programmes [ indigenous people not benefiting } \\
\text { from minerals, demands for small artisanal people to have mining areas] }\end{array}$ \\
\hline & 2) Industrialization [construction of the new and revamping the old industries] 2 \\
\hline & 3) Community participation in agriculture, livestock and fisheries programmes such as \\
\hline & marketing, constructions of warehouses, water dams and reservoirs. \\
\hline & 4) Motivating the investors \\
\hline \multirow{7}{*}{ Human Resource Management [HRM] } & $\begin{array}{l}\text { 1) Migration and Employment [Lack of control in issuances of citizenship certificates, } \\
\text { work permit] }\end{array}$ \\
\hline & 2) Shortage of learning and teaching materials, contributions \\
\hline & 3) Building the capacity of herders, farmers and fishermen and women in their respective \\
\hline & sectors including fish farming training \\
\hline & 4) Increasing number of graduate joining the labour market \\
\hline & 5)Expand employment through industrialization \\
\hline & $\begin{array}{l}\text { 6) To enable graduates from institutions of higher learning and technical colleges to } \\
\text { secure startup capitals }\end{array}$ \\
\hline \multirow[b]{2}{*}{ Policy Analysis and Management [POL] } & 1) Review of regulatory frameworks [weighbridge stations, SUMATRA, EWURA roles] \\
\hline & $\begin{array}{l}\text { 2)Broader understanding of society, special groups [violations of the rights of elderly, } \\
\text { people with disabilities, women and children] }\end{array}$ \\
\hline \multirow{3}{*}{$\begin{array}{l}\text { Public Organizational Development and } \\
\text { Management }[\mathrm{ODM}]\end{array}$} & 1) Government Structure and Public Service \\
\hline & 2) Generating more income and cutting Government Expenditure \\
\hline & 3) Foreign Affairs and International Cooperation and Cooperation at Regional Levels \\
\hline \multirow{2}{*}{ Public Management Ethics [ETH] } & 1) Fight against corruption and Embezzlement \\
\hline & 2) Drug abuse \\
\hline \multirow{4}{*}{ Inter-Governmental Relations [IGR] } & 1) Strengthening of Union \\
\hline & 2) Strengthening the Pillars of State \\
\hline & 3) The Process of Writing New Constitution \\
\hline & 4) Economy and People's expectation \\
\hline
\end{tabular}

Source: [4].

- Strong and competitive Economy [Energy, industry and manufacturing, transportation, mining, agriculture].

- National Tourism and Cultural Heritage [National heritage, tourism].

- Natural Resource Management, environmental climate change [Climate change and eco system, forestry, wildlife].

- Cross Cutting Issues [Governance and accountability, leveraging technologies for socio economic development, entrepreneurship].

The above list of research priorities comprises areas relevant for social science and natural sciences. For the purpose of this paper only issues relevant to the 
public administration discipline will be focused. Table 3 shows categorization of research priority areas relevant for this paper.

The analysis of data from the two knowledge needs pointers reveals that the President's inaugural speech to the Parliament indicated the need for Public Administration research generated knowledge than the NRA priorities. However, the unit standard related research areas could be matched between those from the President's Speech and NRA [13]. Meaning that, the two documents are potential source of the government of Tanzania knowledge needs.

\section{Does TPSLCF Addresses the Core Knowledge Need of the Government? An Assessment}

If competencies offer a language for a nature of leadership in organizations then they should address the most significant facets of leadership roles [22]. In this context, one would expect the Tanzania Public Service Leadership Competency Framework to address the knowledge needs of the government as proposed by the two documents. It must also equip public officials to understand issues and processes of change, and to cope with the risks, ambivalence and uncertainty of the ever changing milieu [29]. In totality, to be instrumental in improving service delivery the competency framework must relate to the adequacy of the knowledge, skills and experience of public officials for coping with present and future challenges [ibid].

But before an assessment is done, a brief overview of Tanzania Public Service Leadership Competency Framework is provided below. The Tanzania Public Service Leadership Competency Framework was developed by the President's Office-Public Service Management [PO-PSM] in 2008. It was envisioned that the leadership competency framework will be a means for ensuring that leadership positions in the Public Service are occupied by people who can demonstrate abilities in openness, innovation, creativity and adaptability to ever change situations [30]. The framework has eight leadership clusters groups with 24 competencies as shown in Table 4.

\section{Methodology}

In order to explore the possibility of whether TPSLCF addresses the core knowledge needs of the government or not, we compare the knowledge need of the government as proposed by Presidential Speech (Table 2) and the National Research priorities (Table 3) with TPSLCF.

To achieve this we invoked two comparisons: A Semantic analysis to reveal the meaning of each data set and a linguistic analysis of actual words used in each data category. Semantic analysis entails coding the underlying meaning present in each data set through content analysis and summary analysis. This is done to capture the semantic content of the texts [22].

The linguistic analysis involves looking at the main themes identified in President Speech (Table 2) and categorization of public administration research areas priorities 2015-2020 (Table 3) and searched for the extent to which they 
Table 3. Categorization of public administration research areas in terms of the national research priority areas $2015-2020$.

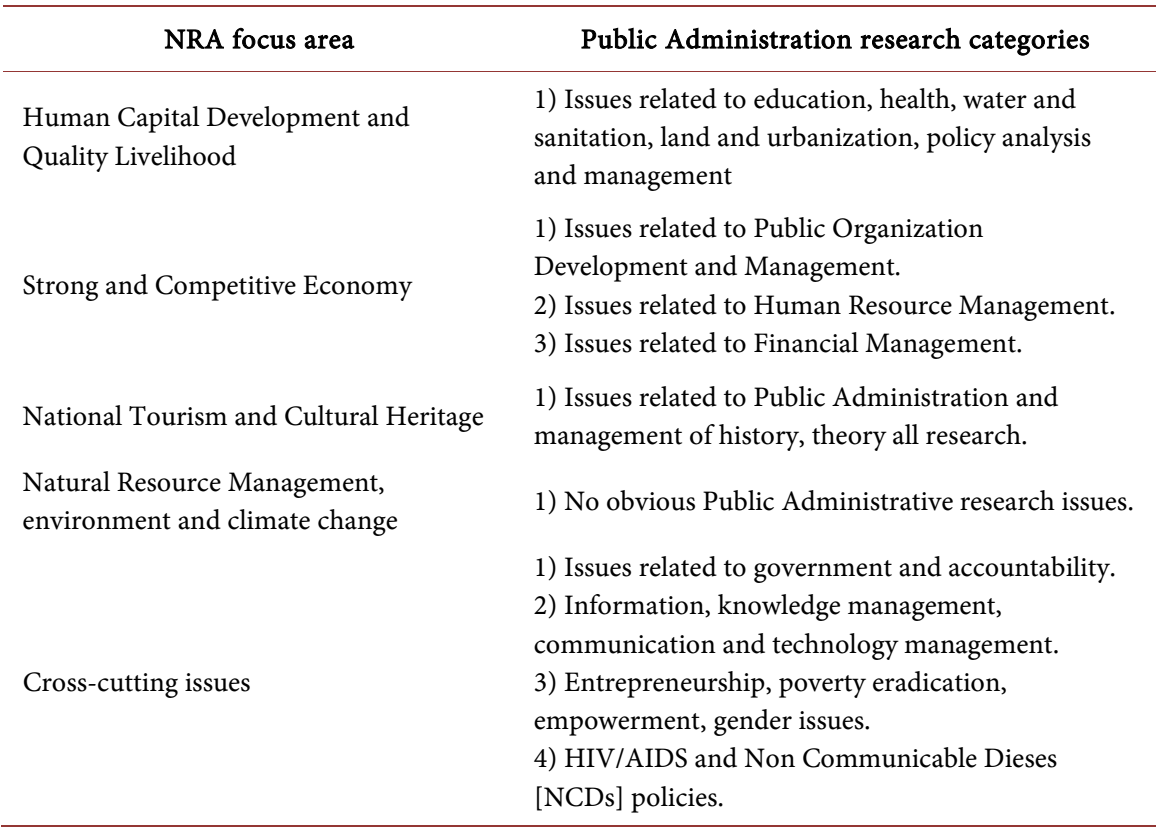

Source: [28].

Table 4. Tanzania public service leadership competency framework.

\section{Leadership Clusters}

1) Sets clear direction

2) Creates shared vision

3) Assesses client needs

4) Promotes continuous innovation

5) Builds effective teams

6) Demonstrates personal mastery

7) Communicates ideas clearly

8) Encourage others' ability

\section{Related Competencies}

1) Facilitates strategic options to deal with change

2) Demonstrates competency/and capability

3) Ensures accountability for performance

1) Builds internal cooperation

2) Ensures Policy adherence

3) Understands internal/external environment

1) Pursues quality - centered improvement

2) Sets performance standards

3) Pursues alternative service delivery

1) Understands core business

2) Manages finances and resources

3) Responds creatively to needs and gaps

1) Provides effectives coaching to others

2) Manages collaborative relations

3) Clarifies roles and expectations

1) Recognizes effect of personal emotions

2) Builds integrity and trust

3) Demonstrates consistent behavior

1) Listens actively to others

2) PClarifies thoughts to be understood

3) Provides and accepts constructive feedback

1) Delegates responsibilities effectively

2) Influences and inspire others

3) Recognizes the work of others

Source: $[30]$ 
were captured within the TPSLCF. This is done to enable a direct comparison of the actual words used rather than just the sense they convey and therefore facilitates quantifiable measures of the extent to which leadership competency framework addressed the government knowledge need [22].

\section{Results and Discussions}

From semantic and linguistic analysis the findings indicate that Tanzania Public Service Leadership Competency Framework TPSLCF to a great extent addresses the majority of issues in both the National Research Area priorities [2015-2020] and the knowledge needs of the government as derived from the President's speech. This finding therefore supports the works of [19] that describes the uses of the competency model and assessment experience.

For example, leadership cluster 1 [sets clear direction] is addressing the unit standard category 1 [Managing Public Service Delivery] in the President's speech, especially on issues dealing with public service and accountability. This leadership cluster can impart technical and analytical thinking skills which improves the regulatory knowledge and analytic competencies of public leaders. Similar observation was also reported by [31] in Ghana.

Similarly, leadership cluster 1 [Sets clear direction] and cluster 8 [Encourage others ability] addresses the National research area priority 1 [Human Capital Development and Quality livelihood]. The two clusters can impart Public leaders with collaborative skills competencies which are relevant in encouraging the team spirit in the public sector.

Equally, the leadership cluster 3 [Asses client needs] addresses the unit standard category 2 [Development management] in the President's Speech and National research priority area 4 [Natural Resource Management, environment and climate change]. These clusters can impart the leadership skills competencies required in line with the country vision 2025 .

Moreover, leadership clusters, 5, 6, 7 and 8 address the unit standard category 3 [Human Resource Management]; 4 [Policy Analysis]; 5 [Public Organizational Development and Management]; 6 [Public Management Ethics]; and 7 [Inter-Governmental Relations] in the President Speech and National research priority area 2 [Strong and Competitive Economy]; 3 [National Tourism and Cultural Heritage] and 4 [Cross cutting issues]. Among others, these clusters can impart the sort of personality traits competencies that would enable senior civil servants to effectively master and explain government policies and programs to citizens and in a way ameliorate false information in the public domain.

As correctly posited by [32] competency models are common place in organizations that aim to prepare workers for future challenges. Tanzania model is not an exceptional. Semantic analysis of Tanzania Public Service Leadership Competency Framework indicates the same features identified by [33] three-tiered pyramid models which includes; personal characteristics such as personality traits; innate talents; skills and knowledge which may be tangible or intangible and specific behaviors that can be observed and measured. Thus, the Tanzania 
Public Service Leadership Competency indicates all the capacities identified by other global competency frameworks. Therefore, if it is rightly utilized it has all the potential to build an efficient and effective envisioned developmental state [34].

Moreover, semantic analysis of the President Speech and NRA priorities areas further reveal a range of issues and concerns including changing nature of the society [concerns for strengthening of union, the pillars of the state, the process of writing new constitution, economy and people's expectations]. All this reveals some insights into current conceptualizations of leadership and management and future expectations.

\section{Public Leadership Competency Framework: Is It a Holy Grail of Service Delivery?}

Leadership competency models are ubiquitous in both private and public sectors [5]. They have been heralded as means for making better talent management decision, recruitment and selection, training and development, rewarding employees, and connected to number of interrelated human resource functions, such as succession planning, compensation and performance management.

Despite the above advantages, the leadership competency frameworks are not the holy grail of service delivery, as noted by scholars elsewhere [35] [36] [37] and [5]. The above data reveal the following;

First and foremost, Tanzania Public Service Leadership Competency Framework has extensively borrowed from other frameworks to represent occupations which are characterized by high degree of uncertainty, unpredictability, it and it customizes work roles rather than represent them holistically [38].

Second, it is not known to majority of institutions in the country despite being in operation for more than 8 years, hence trainings for public servants are organized haphazardly without addressing the core knowledge needs of the government. Yet competency frameworks are expected to help faculty members to design proper curriculum by identifying the society needs.

Third, the framework also tends to focus on measurable behaviors and outcomes to the exclusion of more subtle qualities, interactions and situational factors.

Forth, the Framework is obsolete now, 8 years after its development a lot have happened in the public service milieu.

From the foregoing, suffice to conclude that despite addressing the core knowledge needs of the governments, the Tanzania Public Service Leadership Competency Framework is far from improving services.

\section{Conclusion and Recommendations}

In this article we have attempted to establish whether Tanzania Public Service Leadership Competency Framework addresses the core knowledge needs of the government or not and whether it has the potential to improve public service 
delivery. In so doing, the article has discussed the evolution of competencies globally. We have also discussed the core knowledge needs of Tanzania government and assessed the extent to which the Tanzania Public Service Leadership Competency Framework addresses the core knowledge needs.

The findings indicate that Public Service Leadership Competency Framework to a large extent addresses the core knowledge needs of the government and therefore has the potential to improve public service delivery. However, the findings reveal that TPSLCF borrows much from other global frameworks and it is not well known by the majority of training institutions in the country and has been in use for long time without reviews.

This article, therefore contributes to the global debate on the role of leadership competency framework/models by providing preliminary analysis of Tanzanian case. The take home impression of this findings is that central to competencies approach is the desire to be descriptive and normative. We believe that the difficulty with the frameworks lies in the manner in which they are applied rather than in their content. Therefore, to effectively achieve the descriptive and normative objectives of the Tanzania Public Service Leadership Competency Framework, we suggest the following;

It is the high time now to update and revise the Tanzania Public Service Leadership Competency Framework to reflect the changing nature of work. Competency models normally have a shelf life of less than two years. Tanzania Public Service Leadership competency framework is 8 years old now, obviously it is outdated.

Recently, a group of scholars are advocating the concept of global public services, it is imperative that the review incorporate the global public services competencies as well.

An effort should be done to craft a homegrown Competency Framework Model to legitimatize it and facilitate service delivery.

PO-PSM should popularize the competency framework to the entire public service for public institutions and development providers to utilize the leadership framework for capacity development in the public service and to improve the management of human resources.

\section{Implications for Future Research}

This study used qualitative methods to evaluate the Tanzania Public Service Leadership Competency Framework [TPSCLCF] so as to establish the extent to which it addresses the core knowledge needs of the government. Developing the competencies that address the core knowledge needs of the government is the continual process, therefore the preliminary findings from this study could be further validated through interviews, Focus Group Discussions [FDGs] and Delphi Techniques with the job incumbents and subject experts. A quantitative study in the same area could also be undertaken for comparative purposes to strengthen the findings. 


\section{References}

[1] Rosenbaum, A. (2002) Preparing Public Administrators to Function in a Rapidly Changing World: In African Institutes of Public Administration: New Challenges, New Roles, New Perspectives, A Report of the Third Pan African Conference of Ministers of Civil Service, United Nations, New York, 64-74.

[2] African Union (2010) All Africa Public Sector Innovation Awards, Addis Ababa, Ethiopia.

[3] Rakate, N.F. (2006) Transformation in the South African Public Service: The Case of Service Delivery in the Department of health. Submitted in Partial Fulfillment for the Requirement of the Magister Administration (Public Administration) University of Pretoria.

[4] UNDP (2015) The Speech by H.E. John Pombe Joseph Magufuli, Officially Inaugurating the 11th Parliament of the United Republic of Tanzania, 20th November, 2015. http://tz.one.un.org/

[5] Mau, A.T. (2017) Leadership Competencies for a Global Public Service. International Review of Administrative Sciences, 28, 3-22.

[6] Lodge, M. and Hood, C. (2005) Symposium Introduction. Public Administration, 83, 779-787. https://doi.org/10.1111/j.0033-3298.2005.00475.x

[7] Boyatzis, A.R. (1982) The Competent Manager: A Model for Effective Performance. Wiley, New York.

[8] Daley, D.M. (2002) Strategic Human Resource Management: People and Performance Management in Public Sector. Prentice Hall, Upper Saddle River.

[9] Getha-Taylor, H., Hummert, R., Nalbandian, J. and Silvia, C. (2013) Competency Model Design and Assessment: Findings and Future Directions. Journal of Public Affairs Education, 19, 141-171.

[10] Lane, J. (2000) The Public Sector: Concepts, Models and Approaches. Sage Publications, London.

[11] Tubbs, L.S. and Eric, S. (2006) Exploring Taxonomy of Global Leadership Competencies and Meta-Competencies. Journal of American Academy of Business, 8, 29-34.

[12] Polanyi, M. (1969) Knowing and Being. Routledge and Kegan Paul, London.

[13] Wessels, J.S. (2005) The Challenges of Knowledge Production by Researchers in Public Administration, a South African Perspective. South African Journal of Higher Education, Special Issue, 1499-1515.

[14] Rothwell, J.W. and John, E.L. (1999) Competency Identification, Modeling and Assessment in the USA. International Journal of Training and Development, 3, 90-105. https://doi.org/10.1111/1468-2419.00069

[15] Flanagan, J.C. (1954) The Critical Incidence Technique. Psychology Bulletin, 51, 327-358. https://doi.org/10.1037/h0061470

[16] White, R. (1959) Motivation Reconsidered: The Concept of Competence. Psychological Review, 66, 279-333. https://doi.org/10.1037/h0040934

[17] McClelland, D.C. (1973) Testing for Competence Rather than for "Intelligence". American Psychologist, 28, 1-14. https://doi.org/10.1037/h0034092

[18] McLagan, P. (1980) Competency Models. Training and Development Journal, 34, 12-23.

[19] Spencer, L. and Spencer, S. (1993) Competency at Work: Models for Superior Performance. John Wiley and Sons, Inc., New York. 
[20] Prahalad, C.K. and Hamel, G. (1990) The Core Competence of the Corporation. Harvard Business Review, 68, 79-91.

[21] Vazirani, N. (2010) Competencies and Competency Model-A Brief Overview of Its Development and Application. SIES Journal of Management, 7, 121-131.

[22] Bolden, R. and Jonathan, G. (2006) Leadership Competencies: Time to Change the Tune? Leadership, 2, 147-163. https://doi.org/10.1177/1742715006062932

[23] Miller, L., Rankin, N. and Neathey, F. (2001) Competency Frameworks in UK Organizations. CIPD, London.

[24] Edwards, M. (2005) Social Science Research and Public Policy, Narrowing the Divide. Australian Journal of Public Administration, 64, 68-74. https://doi.org/10.1111/j.1467-8500.2005.00417.x

[25] Baehler, K., Callister, P., Gregory, B., Hawke, G., Ladley, A., Ryan, B., Scott, C., Stephans, B., Walker, A. and Wolf, A. (2005) Surveying Research on New Zealand Government, What Next? Australian Journal of Public Administration, 64, 43-61. https://doi.org/10.1111/j.1467-8500.2005.00415.x

[26] Cameron, R. and McLaverty, L. (2008) Public Administration Research in South Africa: An Assessment of Journal Publications, 1994-2006. Administration Publica, $15,69-96$.

[27] Marijani, R. (2017) Public Administration Research in Tanzania: An Assessment of Journal Publications, 2007-2014. Asian Journal of Humanities and Social Studies, 5, 80-92. https://doi.org/10.24203/ajhss.v5i2.4658

[28] Tanzania Commission for Science and Technology (2016) Research Priorities for Tanzania 2015-2020. Apex Media Limited.

[29] Wessels, S.J. (2000) Equipping Public Officials for the Challenges of Responsible Governance: A South African Perspective on Lifelong Learning. International Review of Administrative Sciences, 66, 311-324.

[30] The President's Office, Public Service Management (2008) The Tanzania Public Service Leadership Competency Framework. Government Printers.

[31] Haruna, F.P. and Lawrence, A.K. (2013) Connecting Good Governance Principles to the Public Affairs Curriculum: The Case of Ghana Institute of Management and Public Administration. Journal of Public Affairs Education, 19, 493-514.

[32] Kormanik, M.B., Lehner, R.D. and Winnick, T.A. (2009) General Competencies for the HRD Scholar-Practitioner: Perspectives from across the Profession. Advances in Developing Human Resources, 11, 486-506.

[33] Lucia, A.D. and Lepsinger, R. (1999) Art and Science of Competency Models. Jossey-Bass, Francisco.

[34] Awortwi, N. (2010) Building New Competencies for Government Administrators and Managers in an Era of Public Sector Reforms: The Case of Mozambique. International Review of Administrative Sciences, 76, 732-748. https://doi.org/10.1177/0020852310381803

[35] Gonger, J. and Ready, D. (2004) Rethinking Leadership Competencies. Leader to Leader, 32, 41-47.

[36] Ingraham, P.W. and Getha-Taylor, H. (2005) Common Sense, Competence, and Talent in the Public Service in the USA. Public Administration, 83, 789-803. https://doi.org/10.1111/j.0033-3298.2005.00476.x

[37] Intaglita, J., Urlich, D. and Smallwood (2000) Leveraging Leadership Competencies 
to Produce Leadership Brand. Human Resource Planning, 23, 12-23.

[38] Lester, S. (1994) Management Standards: A Critical Approach. Competency, 2, 28-31. 